\title{
14. CONGLOMERATE AND SANDSTONE PETROGRAPHY, DEEP SEA DRILLING PROJECT SITE 445, PHILIPPINE SEA
}

\author{
Hidekazu Tokuyama, Ocean Research Institute, University of Tokyo \\ and \\ Makoto Yuasa and Atsuyuki Mizuno, Marine Geology Department, Geological Survey of Japan
}

\begin{abstract}
Conglomerates and sandstones in lithologic unit V at DSDP Site 445 comprise lithic clasts, detrital minerals, bioclasts, and authigenic minerals. The lithic clasts are dominantly plagioclase-phyric basalt and microdolerite, followed by plagioclase-clinopyroxene-phyric basalt, aphyric basalt, chert, and limestone. A small amount of hornblende schist occurs. Detrital minerals are dominantly plagioclase, augite, titaniferous augite, olivine, green to pale-brown hornblende, and dark-brown hornblende, with subordinate chromian spinel, epidote, ilmenite, and magnetite, and minor amounts of diopside, enstatite, actinolite, and aegirine-augite. Bioclasts are Nummulites boninensis, Asterocyclina sp. cf. A. penuria, and some other larger foraminifers.

Correlation of cored and dredged samples indicates that the Daito Ridge is mainly composed of igneous, metamorphic, ultramafic, and sedimentary rocks. The igneous rocks are mafic (probably tholeiitic) and alkalic. The metamorphic rocks are hornblende schist, tremolite schist, and diopside-chlorite schist. The ultramafic rocks are alpinetype peridotites. Mineralogical data suggest that there were two metamorphic events in the Daito Ridge. The older one was intermediate- to high-pressure metamorphism. The younger one was contact metamorphism caused by a Paleocene volcanic event, possibly related to the beginning of spreading of the west Philippine Basin. The ultramafic rocks suffered from the same contact metamorphism.

During the Eocene, exposed volcanic and metamorphic rocks on the uplifted Daito Ridge may have supplied pebble clasts to the surrounding coast and shallow sea bottom. The steep slope offshore may have caused frequent slumping and transportation of the pebble clasts and shallow-water benthic organisms into deeper water, forming the conglomerates and sandstones treated here.
\end{abstract}

\section{INTRODUCTION}

The purpose of this study is to examine the petrography of middle-Eocene conglomerate and sandstone cored in DSDP Hole 445, and to discuss the provenance of these rocks in relation to early-Tertiary geologic events on the Daito Ridge.

Hole 445 is in an east-west-trending, sediment-filled depression within the Daito Ridge, at a depth of about 3400 meters below sea level (Figures 1 and 2). The depression opens both to the northwest and to the southeast, to the Kita-Daito Basin and the Minami-Daito Basin, respectively. The depression is bounded by topographic highs to the north and south with relative heights of as much as $\mathbf{2 0 0 0}$ meters.

Sediments from Hole 445 are dominantly redeposited biogenic components from the upper middle Eocene to the Quaternary (0-645 m; lithologic units I to IV), and dominantly redeposited terrigenous components in the middle Eocene (645-892 m; lithologic unit V). The mid- dle Eocene of unit $\mathrm{V}$ is characterized by thin-bedded to laminated nannofossil mudstone and sandy mudstone with many graded interbeds of conglomerate and sandstone. The lower boundary of this lithosome was not reached. However seismic data indicate that the contact between unit $\mathrm{V}$ and the basement lies only a few tens of meters below the bottom of the hole.

Unit $\mathrm{V}$ is subdivided into three sub-units $(\mathrm{Va}, \mathrm{Vb}$, and $\mathrm{Vc}$, in descending order), on the basis of the proportions of biogenic and terrigenous components and grain size of terrigenous components (Figure 3). Subunit $\mathrm{Va}$ is dominantly greenish-gray to dark-greenishgray nannofossil mudstone to sandy mudstone and nannofossil limestone, with interbeds of conglomerate and sandstone containing larger foraminifers. Sub-unit $\mathrm{Vb}$ consists of dark-greenish-gray, sandy mudstone; mudstone; and conglomerate. Sub-unit Vc is almost exclusively dark-greenish-gray conglomerate and sandstone; the conglomerate is of debris-flow origin. Lithic clasts of the conglomerate tend to increase in size downward 


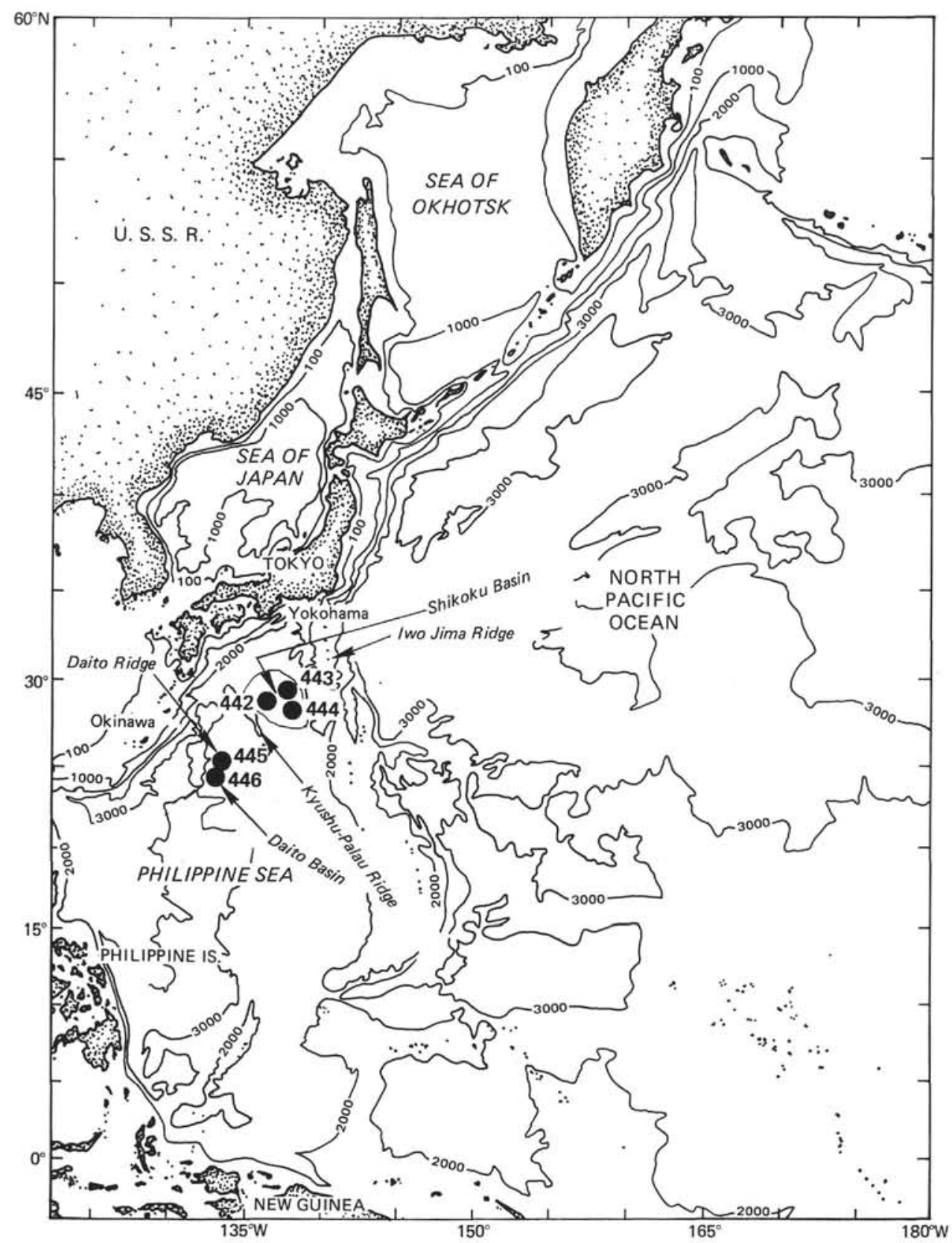

Figure 1. Location of Site 445 and other DSDP sites in the Philippine Sea.

through the unit: in sub-unit Va, they measure several millimeters (average diameter), with a maximum of about $1.5 \mathrm{~cm}$; in sub-units $\mathrm{Vb}$ and $\mathrm{Vc}$, the maximum diameter increases to $3 \mathrm{~cm}$ and $15 \mathrm{~cm}$, respectively. Bioclasts are contained in sub-units $\mathrm{Va}$ and $\mathrm{Vb}$. Microspheric tests of Nummulites boninensis as large as $3 \mathrm{~cm}$ in diameter are visible in considerable numbers in conglomerates of sub-unit Va. The lithology and the primary sedimentary structures of unit $\mathrm{V}$ indicate that it formed by typical canyon or upper-fan resedimentation of shallow-water deposits from the Daito Ridge (Site 445 report, this volume).

A multichannel reflection record (Nasu et al., 1977, 1978; Mizuno et al., 1979) shows that the sedimentary sequence in the depression, as thick as 0.9 to 1.0 seconds in two-way reflection time, can be divided into three acoustic layers (Figure 4). The upper layer, acoustically transparent, is about 0.2 seconds thick and can be correlated with unit I. The middle layer is well-stratified, with high-frequency reflections and a thickness of about 0.54 seconds; we believe that this layer corresponds mostly to the extensive calcareous turbidite deposits of units II and III. The reflectors appear to abut onto the southern wall of the depression. The lower layer, more than 0.2 seconds thick, is characterized by low-frequency reflections and is correlated with unit V. Some of reflectors of the lower layer appear to be intermittently traceable toward the main peak of the Daito Ridge along its northern slope. In addition, velocity data (Nasu et al., 1978) suggest the distribution of materials equivalent to unit $\mathrm{V}$ 


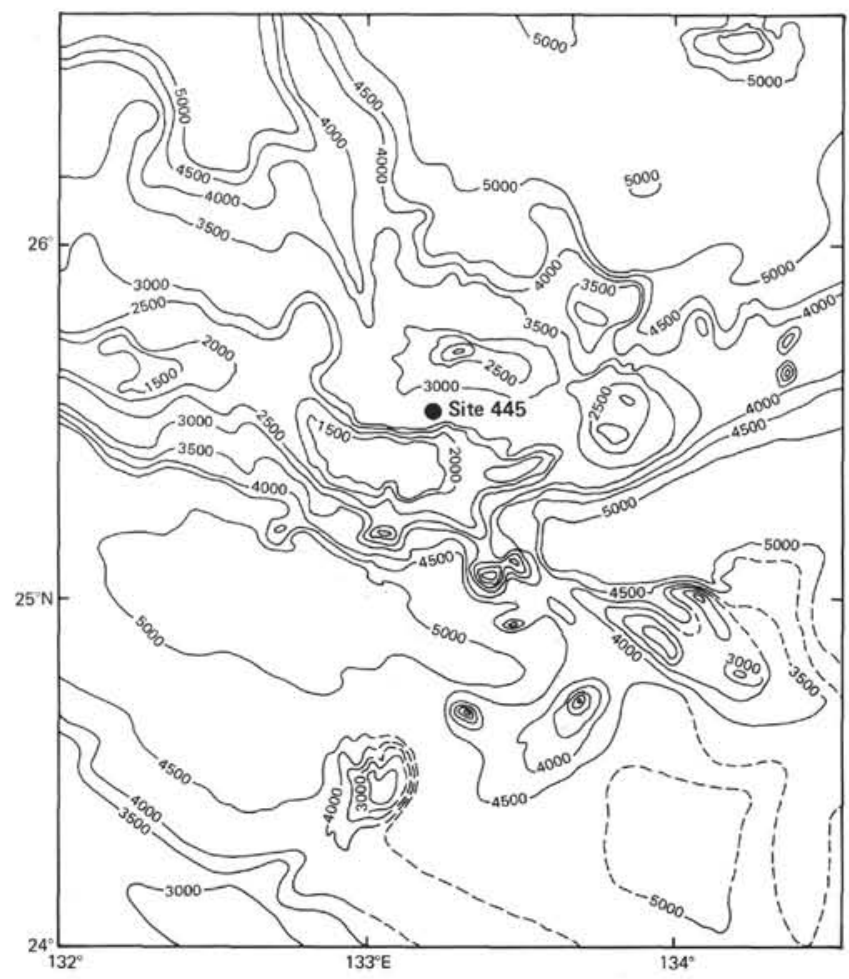

Figure 2. Bathymetry around Site 445, compiled by $H$. Tokuyama. Contours in meters below sea level.

along the slope. This is consistent with the inferred resedimentation of unit V.

Although the geology of the Daito Ridge is not entirely clear, previous work on dredge samples (Mizuno et al., 1977) has shown that the topographic highs are likely underlain by pre-Eocene basement rocks (including metamorphic rocks); middle-Eocene Nummulitesbearing limestone, presumably overlying the basement rocks; and various igneous rocks of unknown age. Citing both geologic and seismic-reflection data, Mizuno et al. (1979) discussed the geologic history of the Daito Ridge during the early to middle Tertiary. They inferred that metamorphic rocks probably underlie the middleEocene shallow-water strata, and that there was volcanic activity on the Daito Ridge during the Eocene, or later, which raised the ridge.

Petrographic study of the cored middle-Eocene conglomerate and sandstone serves to elucidate their provenance geologic events on the Daito Ridge. For this study, 18 samples were selected throughout unit V (Figure 3). They are medium sandstone, coarse sandstone, very coarse sandstone, and granule conglomerate, either greenish gray or dark greenish gray (Table 1). Some of the samples contain bioclasts (Nummulites boninensis and other larger foraminifers). All samples were observed under a microscope, and some were analyzed. In order to correlate with the cored samples, parts of samples dredged from the Daito Ridge (Mizuno et al., 1975; Yuasa and Watanabe, 1977) were re-examined with a microscope and were chemically re-analyzed (Table 2).

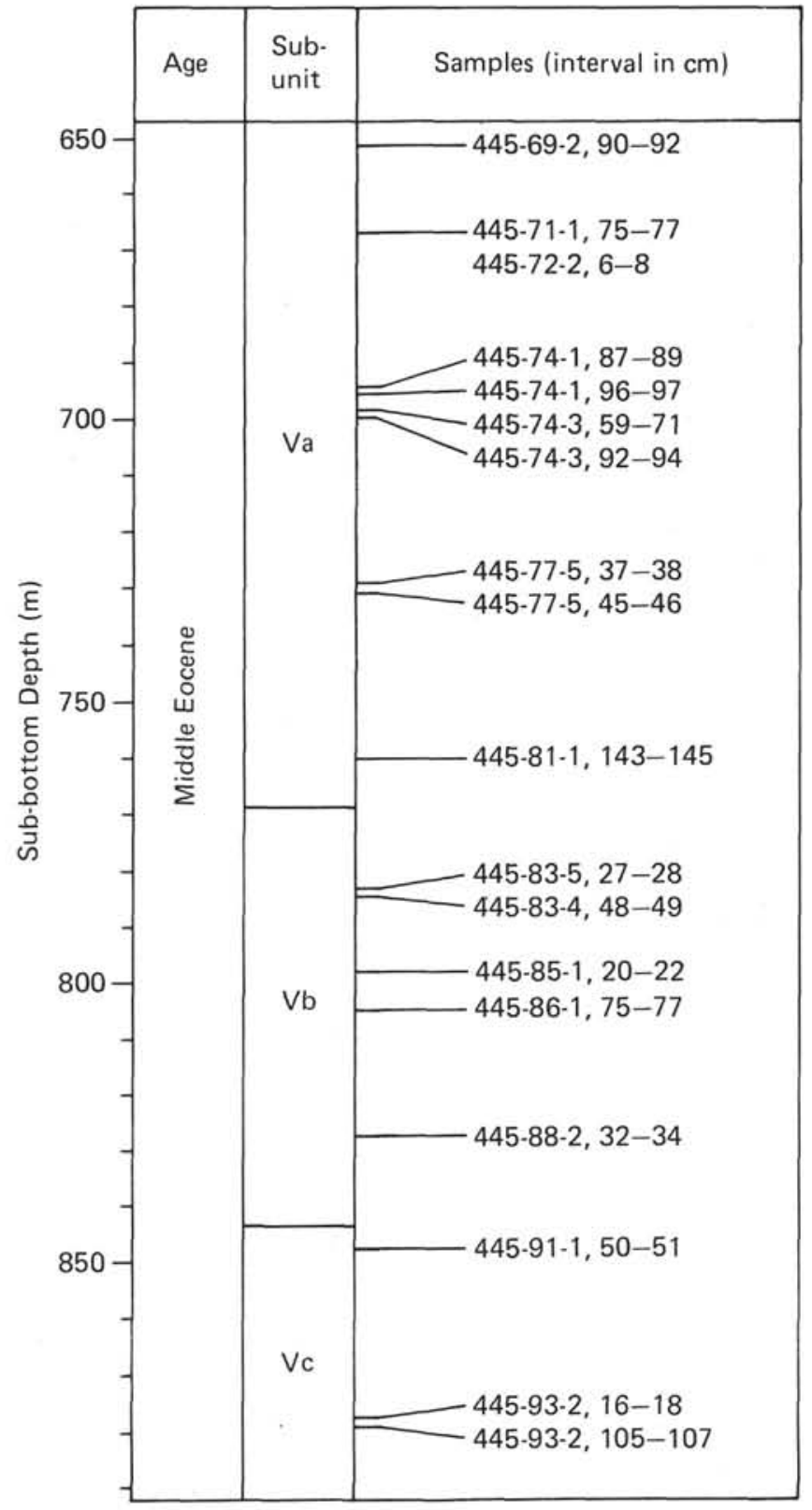

Figure 3. Stratigraphy of lithologic unit V, Hole 445, with sample positions.

\section{PETROGRAPHY OF CONGLOMERATE}

\section{General Descriptions}

Petrography is summarized in Table 3 . Some photomicrographs are shown in Figure 5. The conglomerate and sandstone of unit $\mathrm{V}$ contain lithic clasts, bioclasts, and detrital and authigenic minerals. They have an accessory amount of matrix, comprising nannofossil limestone, nannofossil mudstone, and zeolite which may be a product of alteration of volcaniclastic materials. In many cases, there is grain to grain contact, with no matrix.

The lithic clasts are largely igneous rocks, partly sandstone and chert, and rarely metamorphic rocks. 


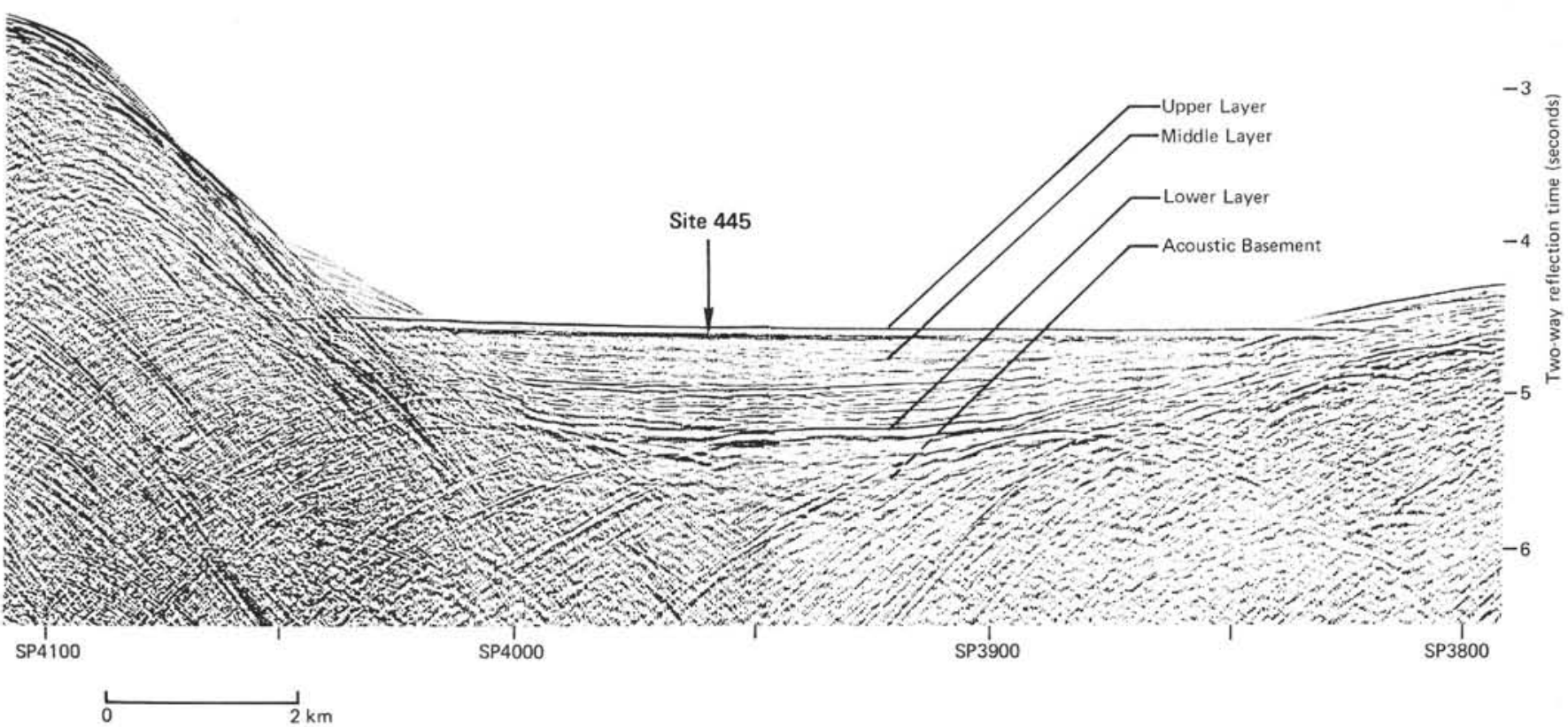

Figure 4. SW-NE multichannel seismic-reflection profile across the depression on the Daito Ridge (profile track is plotted on Figure 5). (The upper layer, middle layer, and lower layer can be correlated with lithologic units I, II and III, and V, respectively. The reflector between the middle and lower layers may represent a chert layer in the middle part of unit IV. Site 445 is about 1 nautical mile northwest of shot point 3960. Its approximate projection onto the seismic line is indicated by an arrow.

They are generally subangular to angular, with varying size. Generally, detrital minerals are dominant in subunit Va, whereas lithic clasts increase downward. The size of lithic clasts is less than $2 \mathrm{~mm}$ in sub-unit $\mathrm{Vb}$, and 2 to $5 \mathrm{~mm}$ in sub-unit Vc. Clasts of limestone with Nummulites boninensis is rarely found. Authigenic components are chert, recrystallized calcite, glauconite, chlorite, and zeolite.

Many bioclasts are present in the samples from subunit $\mathrm{Va}$ and $\mathrm{Vb}$, but very few in those from sub-unit $\mathrm{Vc}$. Most abundant are megalospheric tests of Nummulites boninensis, with sizes of about $0.5 \mathrm{~cm}$ or less; followed by microspheric tests of the same species, as large as 1 $\mathrm{cm}$; and microspheric tests of Asterocyclina sp. cf. A. penuria. Fragmental bryozoans are also found. Some tests, particularly larger ones, are considerably broken, suggesting their incorporation into the conglomerate and sandstone by resedimentation.

\section{Clasts Of Igneous And Metamorphic Rocks}

Clasts of igneous and metamorphic rocks are grouped into five types on the basis of mineral assemblage and texture. All the clasts are moderately to highly altered. They are plagioclase-phyric basalt, microdolerite, plagioclase-clinopyroxene-phyric basalt, aphyric basalt and hornblende schist.

Plagioclase phyric basalt with hyalopilitic to intersertal texture is the dominant type of lithic clast throughout unit V, with lengths of 0.5 to $8 \mathrm{~mm}$. Phenocrysts of plagioclase are lath-shaped and up to $1 \mathrm{~mm}$ in length; compositional zoning is not strong. The groundmass consists of lath-shaped plagioclase, clinopyroxene, and opaque minerals. The opaque minerals are mainly magnetite, with small amounts of ilmenite and hematite. The clinopyroxene is augite, often altered to chlorite. Glass appears as mesostasis, which is largely altered to glauconite and clay minerals.

Microdolerite, with subophitic texture, is a common lithic clast, with lengths of 0.5 to $4 \mathrm{~mm}$. Phenocrysts of plagioclase are lath-shaped and up to $1 \mathrm{~mm}$ in length; they show slight compositional zoning. Microlites are plagioclase, clinopyroxene, and opaque minerals. The clinopyroxene (augite) is often altered to chlorite. Opaque minerals are mainly titanomagnetite, with small amounts of hematite.

Plagioclase-clinopyroxene-phyric basalt is a rare lithic clast throughout unit $\mathrm{V}$, with lengths of 5 to $6 \mathrm{~mm}$. Its mineral assemblage is similar to that of the plagioclasephyric basalt, but it has clinopyroxene (augite) phenocrysts. The clinopyroxene is euhedral to subhedral and has a pale-brownish tint.

Aphyric basalt clasts, rare in general, but common at $445-74-3,92-94 \mathrm{~cm}$, have lengths of 0.5 to $5 \mathrm{~mm}$. Microlites and groundmass consist of plagioclase, opaque minerals, and clinopyroxene. The plagioclase is acicular to lath-shaped. The opaque minerals are acicular or dust-like. The plagioclase and opaque minerals often form spherulitic to dendritic texture. The opaque minerals are mainly titanomagnetite, with small amounts of hematite. The clinopyroxene is augite, often altered to chlorite. Glass appears as a mesostasis, but is largely altered to clay minerals. 
TABLE 1

Sample Descriptions

\begin{tabular}{|c|c|c|}
\hline $\begin{array}{l}\text { Sample } \\
\text { (interval in } \mathrm{cm} \text { ) }\end{array}$ & $\begin{array}{l}\text { Strati- } \\
\text { graphic } \\
\text { Position }\end{array}$ & Visual Description \\
\hline $445-69-2,90-92$ & $\mathrm{Va}$, upper & $\begin{array}{l}\text { Greenish-gray granule conglom- } \\
\text { erate with Nummulites }\end{array}$ \\
\hline $71-1,76-77$ & Va, upper & $\begin{array}{l}\text { Greenish-gray, coarse-grained } \\
\text { sandstone with Nummulites }\end{array}$ \\
\hline $72-2,6-8$ & Va, upper & $\begin{array}{l}\text { Greenish-gray, coarse-grained } \\
\text { sandstone with granule clasts } \\
\text { and calcareous tests }\end{array}$ \\
\hline $74-1,87-89$ & Va, middle & $\begin{array}{l}\text { Dark-greenish-gray, very coarse- } \\
\text { grained sandstone with granule } \\
\text { clasts and Nummulites }\end{array}$ \\
\hline $74-1,96-97$ & Va, middle & $\begin{array}{l}\text { Grayish, very coarse-grained } \\
\text { sandstone with Nummulites }\end{array}$ \\
\hline $74-3,59-61$ & Va, middle & $\begin{array}{l}\text { Greenish-gray, conglomeratic, } \\
\text { very coarse-grained sandstone } \\
\text { with granule clasts and } \\
\text { Nummulites }\end{array}$ \\
\hline $74-3,92-94$ & Va, middle & $\begin{array}{l}\text { Greenish-gray granule conglom- } \\
\text { erate with Nummulites and } \\
\text { pebble clasts of light-gray } \\
\text { Nummulites limestone }\end{array}$ \\
\hline $77-5,37-38$ & $\mathrm{Va}$, lower & $\begin{array}{l}\text { Greenish-gray, medium-grained } \\
\text { sandstone with granule clasts } \\
\text { and calcareous tests }\end{array}$ \\
\hline $77-5,45-46$ & Va, lower & $\begin{array}{l}\text { Greenish-gray granule conglom- } \\
\text { erate with Nummulites }\end{array}$ \\
\hline $81-1,143-145$ & Va, lowest & $\begin{array}{l}\text { Greenish-gray, medium-grained } \\
\text { sandstone with calcareous tests }\end{array}$ \\
\hline $83-4,27-28$ & $\mathrm{Vb}$, upper & $\begin{array}{l}\text { Dark-greenish-gray, medium- } \\
\text { grained sandstone with granule } \\
\text { clasts and fragmental calcare- } \\
\text { ous tests }\end{array}$ \\
\hline $83-4,48-49$ & $\mathrm{Vb}$, upper & $\begin{array}{l}\text { Dark-greenish-gray, very coarse- } \\
\text { grained sandstone with frag- } \\
\text { mental calcareous tests }\end{array}$ \\
\hline $85-1,20-22$ & $\mathrm{Vb}$, middle & $\begin{array}{l}\text { Greenish-gray, medium-grained } \\
\text { sandstone with calcareous tests }\end{array}$ \\
\hline $86-1,75-77$ & $\mathrm{Vb}$, middle & $\begin{array}{l}\text { Dark-greenish-gray, medium- } \\
\text { grained sandstone }\end{array}$ \\
\hline $88-2,32-34$ & $\mathrm{Vb}$, lower & $\begin{array}{l}\text { Dark-greenish-gray, coarse- } \\
\text { grained sandstone }\end{array}$ \\
\hline $91-1,50-51$ & Vc, upper & $\begin{array}{l}\text { Dark-greenish-gray, medium- to } \\
\text { coarse-grained sandstone }\end{array}$ \\
\hline $93-2,16-18$ & Vc, lower & $\begin{array}{l}\text { Dark-greenish-gray conglomer- } \\
\text { ate with granule and pebble } \\
\text { clasts }\end{array}$ \\
\hline $93-2,105-107$ & Vc, lower & $\begin{array}{l}\text { Dark-greenish-gray conglomer- } \\
\text { ate with granule and pebble } \\
\text { clasts }\end{array}$ \\
\hline
\end{tabular}

Hornblende schist occurs as rare lithic clasts with lengths up to $2 \mathrm{~mm}$. It is observed only at $445-83-4$, $27-28 \mathrm{~cm}$. This schist (schistosity is not well developed) is composed of green hornblende, albite, quartz, and unidentified dust-like minerals. Green hornblende, elongate parallel to schistosity, has lengths up to $1 \mathrm{~mm}$.

\section{Detrital Minerals}

Several kinds of detrital minerals were identified: green to pale-brown hornblende, dark-brown hornblende, plagioclase, augite, titaniferous augite, olivine, chromian spinel, opaque minerals, epidote, diopside, aegirine-augite, actinolite, and enstatite.
Green to pale-brown hornblende and dark-brown hornblende, with lengths of less than $1 \mathrm{~mm}$, are common in sub-unit $\mathrm{Va}$, but rare in sub-units $\mathrm{Vb}$ and $\mathrm{Vc}$.

Plagioclase, with lengths of less than $1.5 \mathrm{~mm}$, is the dominant detrital mineral throughout unit V. Some laths are strongly zoned. It is often altered to chlorite or clay minerals in sub-units $\mathrm{Vb}$ and $\mathrm{Vc}$.

Augite and titaniferous augite are common minerals, particularly dominant at $445-83-4,27-28 \mathrm{~cm}$. Cleavage is developed in both types. Titaniferous augite is pale brown, with weak pleochroism.

Olivine pseudomorphs (replaced by serpentine) are also common, with lengths of less than $0.6 \mathrm{~mm}$.

Chromian spinel and opaque minerals are rare throughout unit V, except at $445-83-4,27-28 \mathrm{~cm}$, where they are abundant. The chromian spinel is picotite, with a darkreddish-brown tint and lengths of about $0.5 \mathrm{~mm}$. The opaque minerals, with lengths of up to $0.6 \mathrm{~mm}$, are mainly ilmenite and magnetite, with small amounts of hematite.

Epidote, with lengths up to $0.4 \mathrm{~mm}$, is also rare; it is observed at 445-68-1, 93-94 cm and 445-83-4, 27-28 cm. It is pale greenish and appears as aggregates.

Diopside, enstatite, actinolite, and aegirine-augite were observed, although they occur in very minor amounts in the studied samples.

\section{DREDGE HAULS FROM THE DAITO RIDGE}

During the last several years, many rocks have been dredged from 13 sites on the crest, the uppermost slopes, and the northern peak of the Daito Ridge (Mizuno et al., 1977) (Figure 6). The rocks include igneous rocks, metamorphic rocks, sedimentary rocks, and Nummulites-bearing rocks.

Various kinds of igneous rocks have been reported. Dolerites were collected from the eastern edge of the main body and northern peak of the Daito Ridge (location GDP 15-7). Two-pyroxene andesite, hornblende andesite, hornblende andesite, augite andesite, hornblende-biotite granodiorite, and small amounts of pyroclastic rocks have been also found (locations GDP 15-1, 2, 3, 7, and others) (Mizuno et al., 1975; Ishibashi, 1975; Ishikawa and Aoki, 1978).

Metamorphic rocks which were dredged from the eastern part of the Daito Ridge (location GH 183) (Mizuno et al., 1975) were identified mainly as hornblende schist (Yuasa and Watanabe, 1977). The hornblende schist, whose schistosity is represented by fine alternations of felsic and mafic layers, is mainly composed of hornblende, actinolite, plagioclase, and epidote, with minor amounts of quartz, calcite, ilmenite, and sphene. Yuasa and Watanabe reported that this schist is characterized by low-alkali hornblende, and suggested that it may have formed under low pressure. Tremolite schist was reported as clasts in dredged conglomerate from the same site; it is composed of tremolite, diopside, chlorite, hornblende, and opaque minerals (Yuasa and Watanabe, 1977). In addition, the conglomerate is accompanied by clasts of diopside-chlorite schist and ultramafic rocks. The ultramafic rock contains serpentine, 
TABLE 2

Chemical Analyses (\%) and Calculated Atomic Proportions of Minerals from DSDP Site 445 Cores and Dredged Ultramafic Rocks, Daito Ridge

\begin{tabular}{|c|c|c|c|c|c|c|c|c|c|}
\hline $\begin{array}{c}\text { Com- } \\
\text { ponent }\end{array}$ & $\begin{array}{c}1 \\
\text { Chromian } \\
\text { Spinela }^{\mathrm{a}}\end{array}$ & $\begin{array}{c}2 \\
\text { Chromian } \\
\text { Spinel }^{\mathrm{a}}\end{array}$ & $\begin{array}{c}3 \\
\text { Ch:omian } \\
\text { Spinela }\end{array}$ & Olivine $^{b}$ & Olivine $^{b}$ & $\begin{array}{c}6 \\
\text { Spinelc } \\
\text { (core) }\end{array}$ & $\begin{array}{c}7 \\
\text { Spinelc } \\
\text { (margin) }\end{array}$ & $\begin{array}{c}8 \\
\text { Hornblende }^{d}\end{array}$ & Hornblended \\
\hline $\mathrm{SiO}_{2}$ & - & - & - & 42.07 & 42.23 & 0.25 & 0.27 & 49.29 & 53.13 \\
\hline $\mathrm{Al}_{2} \mathrm{O}_{3}$ & 37.32 & 38.12 & 48.59 & 0.08 & 0.09 & 64.36 & 64.67 & 10.05 & 6.98 \\
\hline $\mathrm{TiO}_{2}$ & - & - & - & 0.07 & 0.10 & 0.00 & 0.00 & 0.94 & 0.70 \\
\hline $\mathrm{FeO}$ & 15.97 & 16.36 & 13.78 & 5.77 & 5.85 & 12.58 & 12.41 & 5.14 & 5.13 \\
\hline $\mathrm{MnO}$ & 0.13 & 0.02 & - & 0.37 & 0.32 & 0.24 & 0.30 & 0.33 & 0.18 \\
\hline $\mathrm{MgO}$ & 14.49 & 14.84 & 17.60 & 51.03 & 50.88 & 21.14 & 22.20 & 19.43 & 19.61 \\
\hline $\mathrm{CaO}$ & 0.13 & 0.12 & 0.04 & 0.03 & 0.09 & 0.03 & 0.00 & 12.47 & 12.55 \\
\hline $\mathrm{Na}_{2} \mathrm{O}$ & - & - & - & 0.00 & 0.00 & 0.05 & 0.02 & 1.04 & 0.68 \\
\hline $\mathrm{K}_{2} \mathrm{O}$ & - & - & - & 0.00 & 0.00 & - & - & - & - \\
\hline $\mathrm{Cr}_{2} \mathrm{O}_{3}$ & 31.88 & 30.55 & 18.96 & 0.08 & 0.14 & 1.45 & 0.30 & 0.06 & 0.00 \\
\hline Total & 99.92 & 100.01 & 98.97 & 99.50 & 99.70 & 100.10 & 100.17 & 98.73 & 98.96 \\
\hline $\mathrm{Si}$ & - & - & - & 1.0145 & 1.0173 & 0.051 & 0.055 & 6.692 & 7.14 \\
\hline $\mathrm{Al}$ & 10.112 & 10.267 & 12.488 & 0.0024 & 0.0027 & 15.332 & 15.342 & 1.607 & 1.105 \\
\hline $\mathrm{Ti}$ & - & - & - & 0.0012 & 0.0018 & 0.000 & 0.000 & 0.096 & 1.105 \\
\hline $\mathrm{Fe}^{+2}$ & 2.977 & 2.912 & 2.270 & 0.1163 & 0.1178 & 1.689 & 1.479 & 0.581 & 0.577 \\
\hline $\mathrm{Fe}^{+3}$ & 0.093 & 0.215 & 0.244 & - & - & 0.437 & 0.610 & - & - \\
\hline $\mathrm{Mn}$ & 0.024 & 0.004 & 0.000 & 0.0075 & 0.0065 & 0.041 & 0.051 & 0.038 & 0.021 \\
\hline $\mathrm{Mg}$ & 4.967 & 5.054 & 5.721 & 1.8345 & 1.8272 & 6.370 & 6.662 & 3.900 & 3.928 \\
\hline $\mathrm{Ca}$ & 0.033 & 0.030 & 0.009 & 0.0007 & 0.0023 & 0.006 & 0.000 & 1.813 & 1.807 \\
\hline $\mathrm{Na}$ & - & - & - & 0.0000 & 0.0000 & 0.018 & 0.010 & 1.273 & 0.177 \\
\hline $\mathrm{K}$ & - & - & - & 0.0000 & 0.0000 & - & - & - & - \\
\hline $\mathrm{Cr}$ & 5.795 & 5.518 & 3.268 & 0.0016 & 0.0027 & 0.231 & 0.048 & 0.007 & 0.000 \\
\hline
\end{tabular}

\footnotetext{
${ }^{\mathrm{a}}$ Core 445-83-4, 27-28 cm; 32 oxygens.

Dredged ultramafic rocks; 4 oxygens.

Dredged ultramafic rocks; 32 oxygens.

Dredged ultramafic rocks; 22.5 oxygens.
}

hornblende, chlorite, spinel, and magnetite, with minor amounts of olivine. The chemical compositions of olivine, spinel, and hornblende are listed in Table 2. The spinel is characterized by greenish spinel $\left(\mathrm{Cr}_{2} \mathrm{O}_{3} 0.3\right.$ wt. \%) rimming a core of reddish-brown spinel $\left(\mathrm{Cr}_{2} \mathrm{O}_{3}\right.$ 1.5 wt. \%). The olivine appears as tiny, irregular remnants within aggregates of serpentine (antigorite) or chlorite. Its composition is $\mathrm{Fo}_{93}$ to $\mathrm{Fo}_{94}$. The hornblende is characterized by low alkali content and occurs sporadically as aggregates or associated with antigorite. The low-alkali hornblende and the antigorite may have been formed by thermal metamorphism (Arai, 1975). This suggests that the ultramafic rocks may have been affected by thermal metamorphism.

Fragments of Nummulites boninensis-bearing limestone, many individual specimens of the species, and Asterocyclina have been reported from several sites at the Daito Ridge (locations GDP 15-4, 7, and others). These in particular indicate upraising of the crestal parts of the Daito Ridge into a shallow-sea environment (Shiki et al., 1977, Mizuno et al., 1979). Oligocene nannofossil chalk also has been reported.

\section{CORRELATION OF CORES AND DREDGED SAMPLES}

The clasts of igneous rocks from Hole 445 are mainly plagioclase-phyric basalt, plagioclase-clinopyroxene-phyric basalt, and microdolerite. Dolerite is also found in the dredged samples. However, dredge hauls from the Daito Ridge contain two-pyroxene andesite and hornblende granodiorite, which were not found in Hole 445 . The heavy mineral analysis of sandstone from lithologic unit V (Sato, this volume) shows that hyperthene, a constituent mineral of two-pyroxene andesite, is rare throughout the unit. Therefore, it is assumed that mafic volcanic activity characterized by plagioclase-phyric basalt, plagioclase-clinopyroxene-phyric basalt, and microdolerite (perhaps a tholeiitic series) was the main volcanic event on the Daito Ridge during or before the deposition of unit V.

This volcanism, coupled with a period of alkali-series volcanism, is suggested by detrital aegirine-augite and titaniferous augite in unit V. Ozima et al. (this volume) report that the age of the plagioclase-clinopyroxenephyric basalt in a clast from Site 445 (Core 93, Section 2; unit $\mathrm{Vc}$ ) is about $59 \mathrm{~m} . \mathrm{y} .\left({ }^{40} \mathrm{Ar} /{ }^{39} \mathrm{Ar}\right.$ method). Therefore, the age of this event is taken to be Paleocene. On the other hand, drilling at Site 446, in the Daito Basin, recovered alkali sills, and the age of these sills is about 60 m.y. ( ${ }^{40} \mathrm{Ar} /{ }^{39} \mathrm{Ar}$ method; Ozima et al., this volume). Therefore, volcanic activity occurred in the Paleocene not only on the Daito Ridge but also in the Daito Basin.

Because east-southeast-trending magnetic lineations south of the central basin fault were identified as anomalies 18 through 21 (Louden, 1976), spreading of the Philippine Basin is thought to have started before 55 
TABLE 3

Petrography of Igneous and Metamorphic Clasts and Detrital Minerals in Conglomerate, Site 445

\begin{tabular}{|c|c|c|c|c|c|}
\hline \multirow{2}{*}{$\begin{array}{c}\text { Sample } \\
\text { (interval in } \mathrm{cm} \text { ) }\end{array}$} & \multicolumn{3}{|c|}{ Igneous and Metamorphic Clasts } & \multicolumn{2}{|c|}{ Detrital Minerals } \\
\hline & Rock Type & Minerals & Remarks & Mineral & Remarks \\
\hline \multicolumn{6}{|l|}{ Unit Va } \\
\hline \multirow[t]{4}{*}{$445-69-2,90-92$} & \multirow[t]{3}{*}{ Pl-phyric basalt } & \multirow{3}{*}{$\begin{array}{l}\text { Phenocryst: } \\
\text { plagioclase } \\
\text { Groundmass: } \\
\text { plagioclase } \\
\text { clinopyroxene } \\
\text { opaque minerals }\end{array}$} & \multirow{3}{*}{$\begin{array}{l}\text { Dominant lithic type; } \\
\text { hyalopilitic to inter- } \\
\text { sertal texture; } \\
\text { size }<1 \mathrm{~mm}\end{array}$} & Plagioclase & $\begin{array}{l}\text { Common mineral; of ten highly } \\
\text { zoned; size }<0.8 \mathrm{~mm}\end{array}$ \\
\hline & & & & Green hornblende & Common mineral; size $<0.5 \mathrm{~mm}$ \\
\hline & & & & $\begin{array}{l}\text { Olivine } \\
\text { pseudomorph }\end{array}$ & $\begin{array}{l}\text { Rare mineral; replaced by ser- } \\
\text { pentine; size }<0.3 \mathrm{~mm}\end{array}$ \\
\hline & Microdolerite & $\begin{array}{l}\text { Phenocryst: } \\
\text { plagioclase } \\
\text { Microlite: } \\
\text { plagioclase } \\
\text { clinopyroxene } \\
\text { opaque minerals }\end{array}$ & $\begin{array}{l}\text { Rare lithic type; } \\
\text { subophitic texture; } \\
\text { size } 1-3 \mathrm{~mm}\end{array}$ & & \\
\hline \multirow[t]{4}{*}{$71-1,76-77$} & \multirow[t]{3}{*}{ Microdolerite } & \multirow{3}{*}{$\begin{array}{l}\text { Phenocryst: } \\
\text { plagioclase } \\
\text { Microlite; } \\
\text { plagioclase } \\
\text { clinopyroxene } \\
\text { opaque minerals }\end{array}$} & \multirow{3}{*}{$\begin{array}{l}\text { Common lithic type; } \\
\text { subophitic texture; } \\
\text { size } 0.6-4 \mathrm{~mm}\end{array}$} & Plagioclase & $\begin{array}{l}\text { Common mineral; } \\
\text { size } 0.2-0.4 \mathrm{~mm}\end{array}$ \\
\hline & & & & $\begin{array}{l}\text { Pale-green } \\
\text { hornblende }\end{array}$ & Rare mineral; size $<0.3 \mathrm{~mm}$ \\
\hline & & & & Brown hornblende & Rare mineral; size $<0.3 \mathrm{~mm}$ \\
\hline & Pl-phyric basalt & $\begin{array}{l}\text { Phenocryst: } \\
\text { plagioclase } \\
\text { Ground mass: } \\
\text { plagioclase } \\
\text { clinopyroxene } \\
\text { opaque minerals }\end{array}$ & $\begin{array}{l}\text { Common lithic type; } \\
\text { hyalopilitic texture; } \\
\text { size } 0.4-1.5 \mathrm{~mm}\end{array}$ & & \\
\hline \multirow[t]{2}{*}{$72-2,6-8$} & \multirow[t]{2}{*}{ Pl-phyric basalt } & $\begin{array}{l}\text { Phenocryst: } \\
\text { plagioclase }\end{array}$ & \multirow{2}{*}{$\begin{array}{l}\text { Common lithic type; } \\
\text { hyalopilitic to inter- } \\
\text { sertal texture; } \\
\text { size } 0.2-0.5 \mathrm{~mm}\end{array}$} & Plagioclase & $\begin{array}{l}\text { Common mineral; often slightly } \\
\text { zoned; size } 0.2-0.3 \mathrm{~mm}\end{array}$ \\
\hline & & $\begin{array}{l}\text { Groundmass: } \\
\text { plagioclase } \\
\text { clinopyroxene } \\
\text { opaque minerals }\end{array}$ & & Green hornblende & Common mineral; size $<0.2 \mathrm{~mm}$ \\
\hline \multirow[t]{6}{*}{$\begin{array}{r}74-1,87-89 \\
96-97\end{array}$} & \multirow[t]{2}{*}{ Pl-phyric basalt } & $\begin{array}{l}\text { Phenocryst: } \\
\text { plagioclase }\end{array}$ & \multirow{2}{*}{$\begin{array}{l}\text { Dominant lithic type; } \\
\text { hyalopilitic to inter- } \\
\text { sertal texture; } \\
\text { size } \sim 1 \mathrm{~mm}\end{array}$} & Green hornblende & Common mineral; size $<1 \mathrm{~mm}$ \\
\hline & & $\begin{array}{l}\text { Ground mass: } \\
\text { plagioclase } \\
\text { clinopyroxene } \\
\text { opaque minerals }\end{array}$ & & Plagioclase & $\begin{array}{l}\text { Common mineral; of ten highly } \\
\text { zoned; size }<1 \mathrm{~mm}\end{array}$ \\
\hline & \multirow[t]{3}{*}{ Microdolerite } & \multirow{3}{*}{$\begin{array}{l}\text { Phenocryst: } \\
\text { plagioclase } \\
\text { Microlite: } \\
\text { plagioclase } \\
\text { clinopyroxene } \\
\text { opaque minerals }\end{array}$} & \multirow{3}{*}{$\begin{array}{l}\text { Common lithic type; } \\
\text { subophitic texture; } \\
\text { size } \sim 2 \mathrm{~mm}\end{array}$} & $\begin{array}{l}\text { Titaniferous } \\
\text { augite }\end{array}$ & $\begin{array}{l}\text { Common mineral; pale brownish; } \\
\text { size }<0.5 \mathrm{~mm}\end{array}$ \\
\hline & & & & Augite & Common mineral; size $<0.5 \mathrm{~mm}$ \\
\hline & & & & $\begin{array}{l}\text { Olivine } \\
\text { pseudomorph }\end{array}$ & Rare mineral; size $<0.6 \mathrm{~mm}$ \\
\hline & Aphyric basalt & $\begin{array}{l}\text { Microlite to } \\
\text { groundmass: } \\
\text { plagioclase } \\
\text { opaque minerals } \\
\text { glass }\end{array}$ & $\begin{array}{l}\text { Rare lithic type; plagi- } \\
\text { oclase and opaque } \\
\text { minerals showing den- } \\
\text { dritic texture; glass } \\
\text { highly altered to clay } \\
\text { minerals; size }<0.5 \mathrm{~mm}\end{array}$ & Brown hornblende & Rare mineral; size $<0.3 \mathrm{~mm}$ \\
\hline $74-3,59-61$ & $\begin{array}{l}\text { Pl-cpx-phyric } \\
\text { basalt }\end{array}$ & $\begin{array}{l}\text { Phenocryst: } \\
\text { plagioclase } \\
\text { clinopyroxene } \\
\text { Groundmass: } \\
\text { plagioclase } \\
\text { clinopyroxene } \\
\text { opaque minerals }\end{array}$ & $\begin{array}{l}\text { Dominant lithic type; } \\
\text { hyalopilitic to inter- } \\
\text { sertal texture; } \\
\text { size } 5-6 \mathrm{~mm}\end{array}$ & Green hornblende & $\begin{array}{l}\text { Common mineral; slightly to } \\
\text { highly altered to chlorite; } \\
\text { size }<1 \mathrm{~mm}\end{array}$ \\
\hline
\end{tabular}

Ma. The volcanic activity in the Daito Ridge and Basin province might have been related to the beginning of spreading of the west Philippine Basin.
Clasts of metamorphic rocks are rare throughout unit V; however, some metamorphic minerals are recognized (hornblende, actinolite, epidote, and diopside; magne- 
TABLE 3 - Continued

\begin{tabular}{|c|c|c|c|c|c|}
\hline \multirow{2}{*}{$\begin{array}{c}\text { Sample } \\
\text { (interval in } \mathrm{cm} \text { ) }\end{array}$} & \multicolumn{3}{|c|}{ Igneous and Metamorphic Clasts } & \multicolumn{2}{|r|}{ Detrital Minerals } \\
\hline & Rock Type & Minerals & Remarks & Mineral & Remarks \\
\hline \multicolumn{6}{|l|}{ Unit Va } \\
\hline \multirow[t]{3}{*}{$445-74-3,92-94$} & Pl-phyric basalt & $\begin{array}{l}\text { Phenocryst: } \\
\text { plagioclase } \\
\text { Groundmass: } \\
\text { plagioclase } \\
\text { clinopyroxene } \\
\text { opaque minerals } \\
\text { glass }( \pm)\end{array}$ & $\begin{array}{l}\text { Dominent lithic type; } \\
\text { size } 1-3 \mathrm{~mm}\end{array}$ & Plagioclase & $\begin{array}{l}\text { Rare mineral; partly altered to } \\
\text { clay minerals; size }<0.3 \mathrm{~mm} \\
\text { (Detrital minerals are rare in this } \\
\text { sample.) }\end{array}$ \\
\hline & Microdolerite & $\begin{array}{l}\text { Phenocryst: } \\
\text { plagioclase } \\
\text { Microlite: } \\
\text { plagioclase } \\
\text { clinopyroxene } \\
\text { opaque minerals }\end{array}$ & $\begin{array}{l}\text { Common lithic type; } \\
\text { subophitic texture; } \\
\text { size 3-4 mm }\end{array}$ & & \\
\hline & Aphyric basalt & $\begin{array}{l}\text { Microlite to } \\
\text { groundmass: } \\
\text { plagioclase } \\
\text { clinopyroxene } \\
\text { opaque minerals } \\
\text { glass }\end{array}$ & $\begin{array}{l}\text { Common lithic type; } \\
\text { clinopyroxene and } \\
\text { glass are highly altered } \\
\text { to clay; size } 1-5 \mathrm{~mm}\end{array}$ & & \\
\hline \multirow[t]{3}{*}{$77-5,37-38$} & \multirow[t]{3}{*}{ Pl-phyric basalt } & \multirow{3}{*}{$\begin{array}{l}\text { Phenocryst: } \\
\text { plagioclase }\end{array}$} & \multirow{3}{*}{$\begin{array}{l}\text { Rare lithic type; inter- } \\
\text { sertal texture; clinopy- } \\
\text { roxene is highly al- } \\
\text { tered; size } \sim 0.2 \mathrm{~mm} \\
\text { (Lithic clast are rare } \\
\text { in this sample.) }\end{array}$} & Plagioclase & Rare mineral; size $0.3-0.4 \mathrm{~mm}$ \\
\hline & & & & $\begin{array}{l}\text { Pale-green } \\
\text { hornblende }\end{array}$ & Rare mineral; size $\sim 0.2 \mathrm{~mm}$ \\
\hline & & & & Opaque minerals & $\begin{array}{l}\text { Rare mineral; size }<0.2 \mathrm{~mm} \\
\text { (Detrital minerals are rare in this } \\
\text { sample.) }\end{array}$ \\
\hline \multirow[t]{2}{*}{$77-5,45-46$} & Microdolerite & $\begin{array}{l}\text { Microphenocryst: } \\
\text { plagioclase } \\
\text { Microlite: } \\
\text { plagioclase } \\
\text { clinopyroxene } \\
\text { opaque minerals }\end{array}$ & $\begin{array}{l}\text { Common lithic type; } \\
\text { subophitic texture; } \\
\text { size } 1-1.5 \mathrm{~mm}\end{array}$ & & \\
\hline & Pl-phyric basalt & $\begin{array}{l}\text { Phenocryst: } \\
\text { plagioclase } \\
\text { Microlite to } \\
\text { groundmass: } \\
\text { plagioclase } \\
\text { clinopyroxene } \\
\text { opaque minerals }\end{array}$ & $\begin{array}{l}\text { Common lithic type; } \\
\text { intersertal texture; } \\
\text { size } 2-3 \mathrm{~mm}\end{array}$ & & \\
\hline \multirow[t]{2}{*}{$81-1,143-145$} & Microdolerite & $\begin{array}{l}\text { Phenocryst: } \\
\text { plagioclase } \\
\text { Microlite: } \\
\text { plagioclase } \\
\text { clinopyroxene } \\
\text { opaque minerals }\end{array}$ & $\begin{array}{l}\text { Common lithic type; } \\
\text { subophitic texture; } \\
\text { size } 1-2 \mathrm{~mm}\end{array}$ & Plagioclase & Common mineral; size $<0.2 \mathrm{~mm}$ \\
\hline & Pl-phyric basalt & $\begin{array}{l}\text { Phenocryst: } \\
\text { plagioclase } \\
\text { Microlite to } \\
\text { groundmass: } \\
\text { plagioclase } \\
\text { clinopyroxene } \\
\text { opaque minerals }\end{array}$ & $\begin{array}{l}\text { Common lithic type; } \\
\text { intersertal texture; } \\
\text { size } 1.5-2.0 \mathrm{~mm}\end{array}$ & & \\
\hline
\end{tabular}

tite and ilmenite are partly of metamorphic origin). Hornblende schist, tremolite schist, and diopside-chlorite schist were found among dredged rocks. There seems to be good correlation between the metamorphic minerals from cored and dredged samples. In the hornblende schist from the Daito Ridge, hornblende and epidote occur together with albite-andesine (Yuasa and Watan- abe, 1977). Hornblende coexists with albite in intermediate- and high-pressure regional metamorphism (Miyashiro, 1973). The hornblende in this schist is characterized in its low alkali content and it coexists with small amounts of K-feldspar; such hornblende occurs in contact metamorphic aureoles. On the other hand, it is assumed that the schistosity of this rock has resulted from 
TABLE 3 - Continued

\begin{tabular}{|c|c|c|c|c|c|}
\hline \multirow{2}{*}{$\begin{array}{c}\text { Sample } \\
\text { (interval in cm) }\end{array}$} & \multicolumn{3}{|c|}{ Igneous and Metamorphic Clasts } & \multicolumn{2}{|c|}{ Detrital Minerals } \\
\hline & Rock Type & Minerals & Remarks & Mineral & Remarks \\
\hline \multicolumn{6}{|l|}{ Unit $\mathrm{Vb}$} \\
\hline \multirow[t]{3}{*}{$445-83-4,27-28$} & \multirow[t]{2}{*}{ Pl-phyric basalt } & \multirow[t]{2}{*}{$\begin{array}{l}\text { Phenocryst: } \\
\text { plagioclase } \\
\text { Groundmass: } \\
\text { plagioclase } \\
\text { clinopyroxene } \\
\text { opaque minerals } \\
\text { glass }( \pm)\end{array}$} & \multirow[t]{2}{*}{$\begin{array}{l}\text { Rare lithic type; } \\
\text { size } \sim 2 \mathrm{~mm} \\
\text { (Lithic clasts are rare } \\
\text { in this sample.) }\end{array}$} & $\begin{array}{l}\text { Opaque minerals } \\
\text { Chromian spinel } \\
\text { Augite } \\
\text { Olivine } \\
\text { pseudomorph }\end{array}$ & $\begin{array}{l}\text { Dominant mineral; size }<0.6 \mathrm{~mm} \\
\text { Common mineral; size } \sim 0.5 \mathrm{~mm} \\
\text { Common mineral; size }<0.2 \mathrm{~mm} \\
\text { Common mineral; altered to ser- } \\
\text { pentine or clay minerals; } \\
\text { size }<0.6 \mathrm{~mm}\end{array}$ \\
\hline & & & & Titaniferous augite & Rare mineral; size $<0.2 \mathrm{~mm}$ \\
\hline & Hb schist & $\begin{array}{l}\text { Hornblende } \\
\text { Albite } \\
\text { Quartz }\end{array}$ & $\begin{array}{l}\text { Rare lithic type; } \\
\text { highly to moderately } \\
\text { altered; size } 2 \mathrm{~mm}\end{array}$ & $\begin{array}{l}\text { Green hornblende } \\
\text { Epidote }\end{array}$ & $\begin{array}{l}\text { Rare mineral; size }<0.2 \mathrm{~mm} \\
\text { Rare mineral; size }<0.4 \mathrm{~mm} \\
\text { (Detrital minerals are abundant } \\
\text { in this sample.) }\end{array}$ \\
\hline \multirow[t]{3}{*}{$83-4,48-49$} & Pl-phyric basalt & $\begin{array}{l}\text { Phenocryst: } \\
\text { plagioclase } \\
\text { Groundmass: } \\
\text { plagioclase } \\
\text { clinopyroxene } \\
\text { opaque minerals }\end{array}$ & $\begin{array}{l}\text { Dominant lithic type; } \\
\text { intersertal texture; } \\
\text { opaque minerals acicu- } \\
\text { lar; size } \sim 2 \mathrm{~mm}\end{array}$ & \multirow[t]{3}{*}{ Plagioclase } & \multirow[t]{3}{*}{$\begin{array}{l}\text { Dominant mineral; of ten slightly } \\
\text { zoned; size }<1 \mathrm{~mm}\end{array}$} \\
\hline & Microdolerite & $\begin{array}{l}\text { Phenocryst: } \\
\text { plagioclase } \\
\text { Microlite: } \\
\text { plagioclase } \\
\text { clinopyroxene } \\
\text { opaque minerals }\end{array}$ & $\begin{array}{l}\text { Common lithic type; } \\
\text { subophitic texture; } \\
\text { size }<1.5 \mathrm{~mm}\end{array}$ & & \\
\hline & Aphyric basalt & $\begin{array}{l}\text { Microlite to } \\
\text { groundmass: } \\
\text { clinopyroxene } \\
\text { opaque minerals } \\
\text { glass }\end{array}$ & $\begin{array}{l}\text { Rare lithic type; } \\
\text { plagioclase shows } \\
\text { quench morphology; } \\
\text { size } \sim 2 \mathrm{~mm}\end{array}$ & & \\
\hline \multirow[t]{2}{*}{$85-1,20-22$} & Pl-phyric basalt & $\begin{array}{l}\text { Phenocryst: } \\
\text { plagioclase } \\
\text { Groundmass: } \\
\text { plagioclase } \\
\text { clinopyroxene } \\
\text { opaque minerals } \\
\text { glass }\end{array}$ & $\begin{array}{l}\text { Rare lithic type; } \\
\text { hyalopilitic texture; } \\
\text { clinopyroxene and } \\
\text { glass are highly } \\
\text { altered; size } \sim 2 \mathrm{~mm}\end{array}$ & \multirow[t]{2}{*}{ Plagioclase } & \multirow[t]{2}{*}{$\begin{array}{l}\text { Common mineral; } \\
\text { size } 0.2-0.3 \mathrm{~mm}\end{array}$} \\
\hline & Microdolerite & $\begin{array}{l}\text { Microphenocryst: } \\
\text { plagioclase } \\
\text { Microlite: } \\
\text { plagioclase } \\
\text { clinopyroxene } \\
\text { opaque minerals }\end{array}$ & $\begin{array}{l}\text { Rare lithic type; } \\
\text { subophitic texture; } \\
\text { clinopyroxene altered; } \\
\text { size } \sim 0.5 \mathrm{~mm}\end{array}$ & & \\
\hline \multirow[t]{3}{*}{$86-1,75-77$} & \multirow[t]{2}{*}{ Microdolerite } & \multirow{2}{*}{$\begin{array}{l}\text { Microphenocryst: } \\
\text { plagioclase } \\
\text { clinopyroxene } \\
\text { Microlite; } \\
\text { plagioclase } \\
\text { clinopyroxene } \\
\text { opaque minerals }\end{array}$} & \multirow{2}{*}{$\begin{array}{l}\text { Common lithic type; } \\
\text { subophitic texture; } \\
\text { size }<0.5 \mathrm{~mm}\end{array}$} & Plagioclase & $\begin{array}{l}\text { Dominant mineral; of ten slightly } \\
\text { zoned; size } 0.2-0.4 \mathrm{~mm}\end{array}$ \\
\hline & & & & Opaque minerals & Common mineral; size $<0.4 \mathrm{~mm}$ \\
\hline & Pl-phyric basalt & $\begin{array}{l}\text { Microphenocryst: } \\
\text { plagioclase } \\
\text { Groundmass: } \\
\text { plagioclase } \\
\text { clinopyroxene } \\
\text { opaque minerals }\end{array}$ & $\begin{array}{l}\text { Common lithic type; } \\
\text { hyalopilitic to inter- } \\
\text { sertal texture; highly } \\
\text { altered; size } \sim 0.5 \mathrm{~mm}\end{array}$ & & \\
\hline
\end{tabular}

intermediate- to high-pressure regional metamorphism, rather than contact metamorphism. Therefore, the metamorphic rock in the Daito Ridge may have undergone two different types of metamorphism: intermediate- to high-pressure regional metamorphism in the pre-Paleocene, and contact metamorphism related to Paleocene volcanic activity. The age of this schist is $49 \pm 3.7 \mathrm{~m} . \mathrm{y}$. (Mizuno et al., unpublished data; determined by the 
TABLE 3 - Continued

\begin{tabular}{|c|c|c|c|c|c|}
\hline \multirow{2}{*}{$\begin{array}{c}\text { Sample } \\
\text { (interval in } \mathrm{cm} \text { ) }\end{array}$} & \multicolumn{3}{|c|}{ Igneous and Metamorphic Clasts } & \multicolumn{2}{|c|}{ Detrital Minerals } \\
\hline & Rock Type & Minerals & Remarks & Mineral & Remarks \\
\hline \multicolumn{6}{|l|}{ Unit $\mathrm{Vb}$} \\
\hline \multirow[t]{3}{*}{$445-88-2,32-34$} & \multirow[t]{2}{*}{ Microdolerite } & \multirow{2}{*}{$\begin{array}{l}\text { Microphenocryst: } \\
\text { plagioclase } \\
\text { Microlite: } \\
\text { plagioclase } \\
\text { clinopyroxene } \\
\text { opaque minerals }\end{array}$} & \multirow{2}{*}{$\begin{array}{l}\text { Common lithic type; } \\
\text { subophitic texture; } \\
\text { size } 1-1.5 \mathrm{~mm}\end{array}$} & Plagioclase & $\begin{array}{l}\text { Dominant mineral; } \\
\text { size } 0.1-0.4 \mathrm{~mm}\end{array}$ \\
\hline & & & & Opaque minerals & $\begin{array}{l}\text { Common mineral; } \\
\text { size } 0.1-0.2 \mathrm{~mm}\end{array}$ \\
\hline & Pl-phyric basalt & $\begin{array}{l}\text { Microphenocryst: } \\
\text { plagioclase } \\
\text { Groundmass: } \\
\text { plagioclase } \\
\text { clinopyroxene } \\
\text { opaque minerals }\end{array}$ & $\begin{array}{l}\text { Common lithic type; } \\
\text { intersertal texture; } \\
\text { clinopyroxene highly } \\
\text { altered; size }<1.2 \mathrm{~mm}\end{array}$ & & \\
\hline \multirow[t]{3}{*}{$445-91-1,50-51$} & Apyric basalt & $\begin{array}{l}\text { Microlite to } \\
\text { groundmass: } \\
\text { plagioclase } \\
\text { opaque minerals } \\
\text { glass }\end{array}$ & $\begin{array}{l}\text { Common lithic type; } \\
\text { plagioclase and opaque } \\
\text { minerals show den- } \\
\text { dritic texture; glass } \\
\text { highly altered to clay } \\
\text { minerals; size }<2 \mathrm{~mm}\end{array}$ & & \\
\hline & Pl-phyric basalt & $\begin{array}{l}\text { Phenocryst: } \\
\text { plagioclase } \\
\text { Groundmass: } \\
\text { plagioclase } \\
\text { clinopyroxene } \\
\text { glass }\end{array}$ & $\begin{array}{l}\text { Common lithic type; } \\
\text { hyalopilitic to inter- } \\
\text { sertal texture; glass } \\
\text { highly altered; } \\
\text { size } 0.5-1.0 \mathrm{~mm}\end{array}$ & & \\
\hline & Microdolerite & $\begin{array}{l}\text { Microphenocryst: } \\
\text { plagioclase } \\
\text { clinopyroxene } \\
\text { Microlite: } \\
\text { plagioclase } \\
\text { clinopyroxene }\end{array}$ & $\begin{array}{l}\text { Common lithic type; } \\
\text { subophitic texture; } \\
\text { clinopyroxene moder- } \\
\text { ately altered; } \\
\text { size } 0.7 \mathrm{~mm}\end{array}$ & & \\
\hline \multirow[t]{2}{*}{$93-2,16-18$} & Pl-phyric basalt & $\begin{array}{l}\text { Phenocryst: } \\
\text { plagioclase } \\
\text { Groundmass to } \\
\text { microlite: } \\
\text { plagioclase } \\
\text { clinopyroxene } \\
\text { opaque minerals }\end{array}$ & $\begin{array}{l}\text { Dominant lithic type; } \\
\text { intersertal to hyalopi- } \\
\text { litic texture; skeletal } \\
\text { opaque grains; } \\
\text { size } 2-8 \mathrm{~mm}\end{array}$ & & \\
\hline & A phyric basalt & $\begin{array}{l}\text { Microlite to } \\
\text { groundmass: } \\
\text { plagioclase } \\
\text { opaque minerals } \\
\text { glass }\end{array}$ & $\begin{array}{l}\text { Rare lithic type; } \\
\text { plagioclase shows } \\
\text { quench morphology; } \\
\text { glass mostly altered to } \\
\text { glauconite; size }<1 \mathrm{~mm}\end{array}$ & & \\
\hline \multirow[t]{3}{*}{$93-2,105-107$} & Pl-phyric basalt & $\begin{array}{l}\text { Phenocryst: } \\
\text { plagioclase } \\
\text { Groundmass: } \\
\text { plagioclase } \\
\text { clinopyroxene } \\
\text { opaque minerals } \\
\text { glass }( \pm)\end{array}$ & $\begin{array}{l}\text { Dominant lithic type; } \\
\text { intersertal to hyalopi- } \\
\text { litic texture; } \\
\text { size } 2-3 \mathrm{~mm}\end{array}$ & Plagioclase & $\begin{array}{l}\text { Rare mineral; size } \sim 0.3 \mathrm{~mm} \\
\text { (Detrital minerals are rare in this } \\
\text { sample.) }\end{array}$ \\
\hline & Microdolerite & $\begin{array}{l}\text { Phenocryst: } \\
\text { plagioclase } \\
\text { clinopyroxene } \\
\text { opaque minerals } \\
\text { glass }( \pm)\end{array}$ & $\begin{array}{l}\text { Common lithic type; } \\
\text { subophitic texture; } \\
\text { size } \sim 2 \mathrm{~mm}\end{array}$ & & \\
\hline & A phyric basalt & $\begin{array}{l}\text { Microlite to } \\
\text { groundmass: } \\
\text { plagioclase } \\
\text { clinopyroxene } \\
\text { opaque minerals } \\
\text { glass }\end{array}$ & $\begin{array}{l}\text { Rare lithic type; } \\
\text { size } \sim 1 \mathrm{~mm}\end{array}$ & & \\
\hline
\end{tabular}




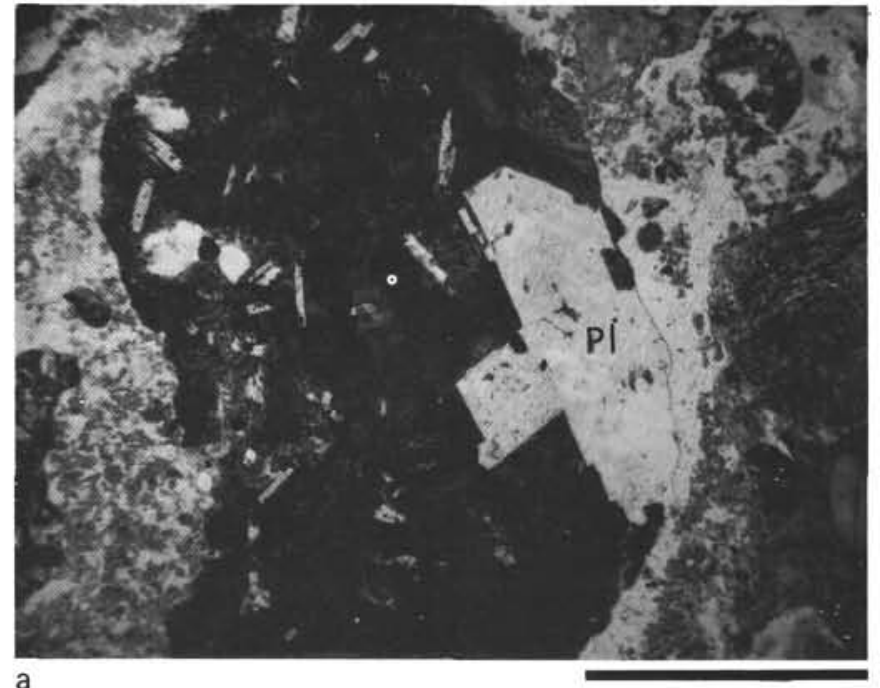

$1.00 \mathrm{~mm}$

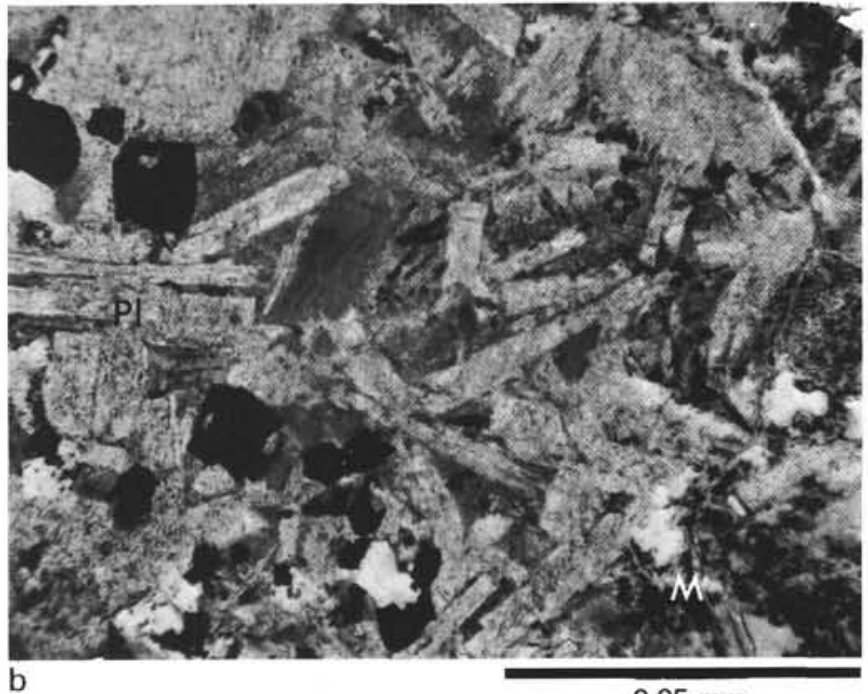

$0.05 \mathrm{~mm}$

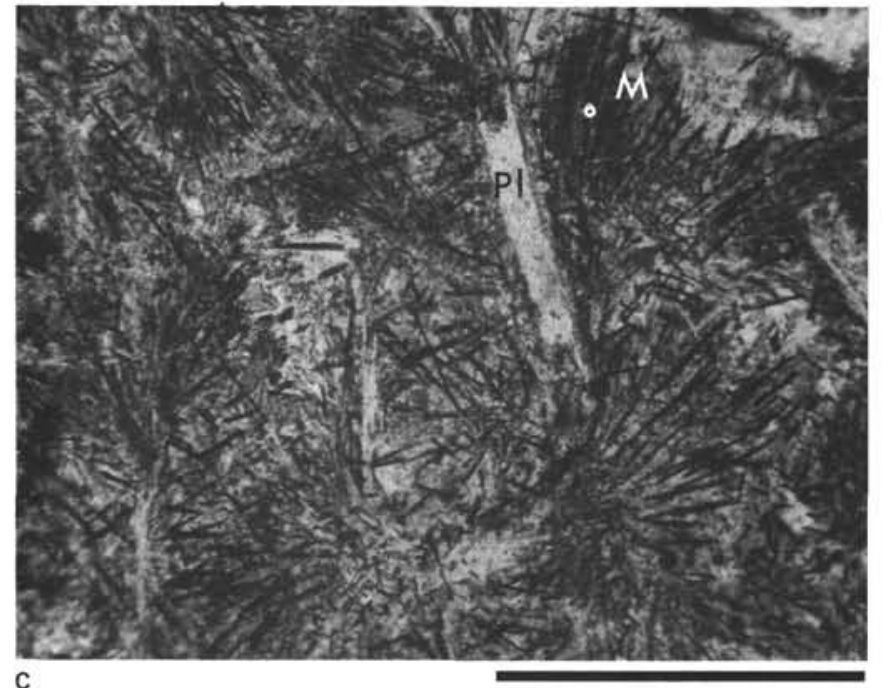

$0.025 \mathrm{~mm}$

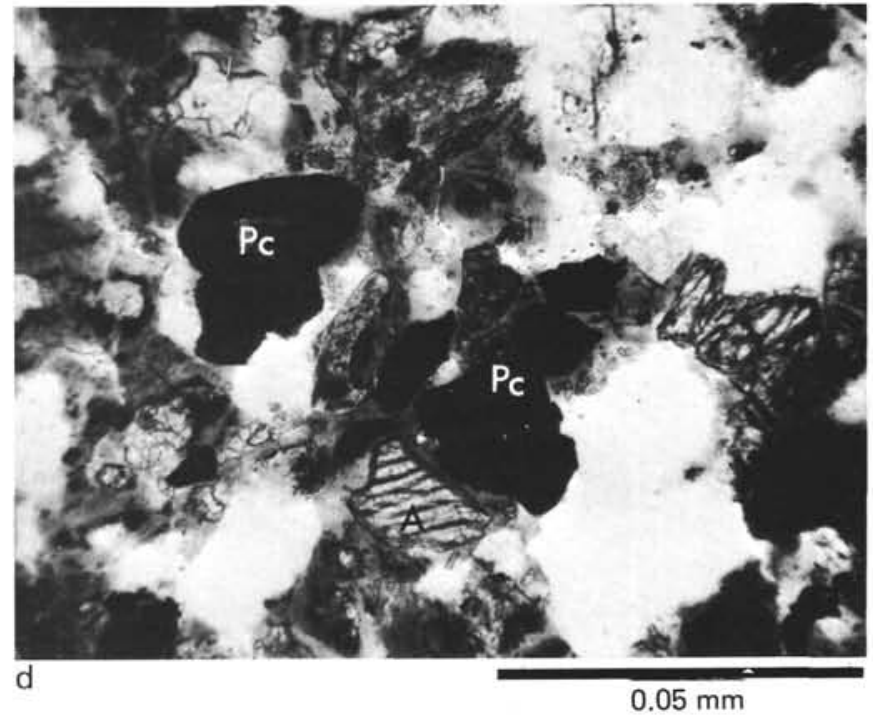

Figure 5. Photomicrographs of (A) plagioclase phyric basalt (445-69-2, 90-92 cm); (B) microdolerite (445-93-2, 105$107 \mathrm{~cm}$ ); (C) aphyric basalt (445-74-1, 96-97 cm); and (D) picotite and other detrital minerals (445-83-4, 27-28 cm).

$\mathrm{K} /$ Ar method, using hornblende separated from the sample). This age may indicate the second metamorphic event.

The 10-m.y. difference between the ages of the basalt and the schist can be attributed to alteration of the hornblende. The age of the schist $(49 \pm 3.7 \mathrm{~m} . \mathrm{y}$.) should be taken to be the minimum age of the metamorphism.

Some ultramafic detrital minerals are recognized (chromian spinel, serpentine pseudomorphs after olivine, magnetite, and enstatite), although clasts of ultramafic rocks were not found in the cores from Site 445. The chemical composition of the chromian spinels is shown in Table 2 . The analyses were recast in structural formulas on the basis of 32 oxygens. Total Fe was partitioned between $\mathrm{A}$ and $\mathrm{B}$ sites as $\mathrm{Fe}^{2+}$ and $\mathrm{Fe}^{3+}$ in the proportions required for stoichiometry (Finger, 1972), yielding an estimate of the amount of ferric iron in the spinel. From the covariation of $\mathrm{Fe}^{3+} /\left(\mathrm{Fe}^{3+}+\mathrm{Cr}+\mathrm{Al}\right)$ and $\mathrm{Mg} /\left(\mathrm{Mg}+\mathrm{Fe}^{2+}\right)$ in spinel (Figure 7), it can be seen that these chromian spinels are characterized by low $\mathrm{Fe}^{3+}$ content, and they plot in the field of alpine-type peridotites.

Considering that chromian spinel in the cores must have been derived from the Daito Ridge, the dredged ultramafic rocks are assumed to be thermally metamorphosed alpine-type peridotite, and the basement of the Daito Ridge is assumed to be partly composed of this peridotite. This thermal metamorphism also is assumed to have been caused by the Paleocene volcanic activity. Therefore, the age of the ultramafic rocks may be prePaleocene.

The bioclasts from unit V (Nummulites boninensis, Asterocyclina sp. cf. A. penuria, etc.) are quite consistent with the dredge-sample data. This implies that unit $\mathrm{V}$ (at least sub-units $\mathrm{Va}$ and $\mathrm{Vb}$ ) and the Nummulitesbearing strata on the ridge are nearly the same age, in- 


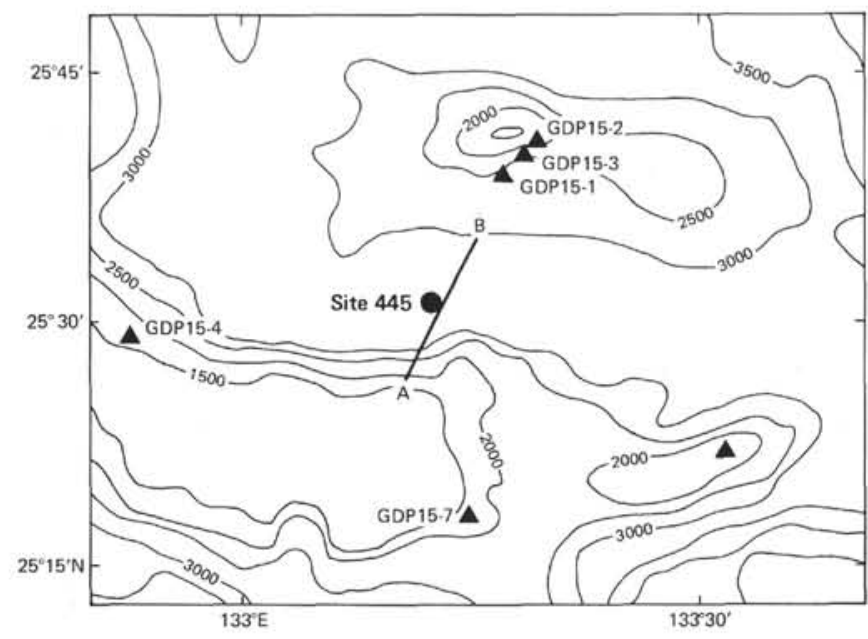

Figure 6. Dredge sampling sites in the vicinity of Site 445. Line $A-B$ is the track of the multichannel seismic-reflection record of Figure 4.

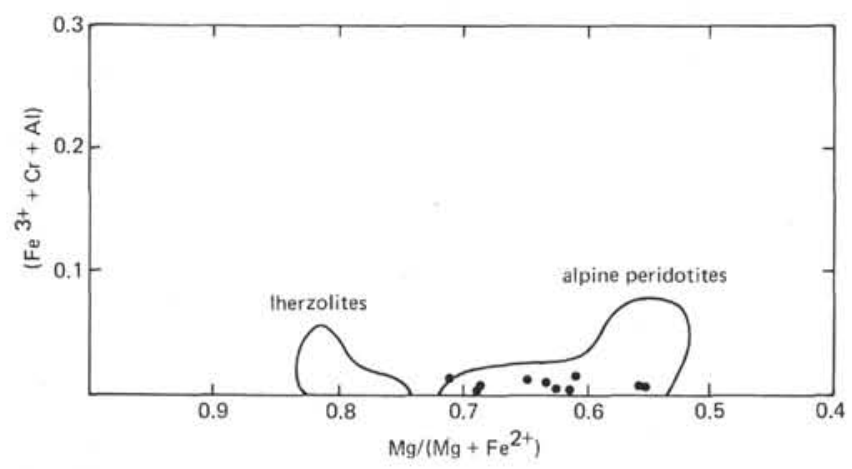

Figure 7. Compositions of chromian spinel from Site 445 (lithologic unit Vc; Core 83, Section 4). The compositional field of spinels from lherzolites is from O'Hara et al. (1971) and Littlejohn and Greenwood (1974); the field for spinels from alpine-type peridotites is from Loney et al. (1971).

dicating transport of the sedimentary materials from shallow water to the bottom of the depression.

The available data (Table 4), demonstrate that the clastic and bioclastic materials of the conglomerate and sandstone in unit $\mathrm{V}$ must have been supplied from the upraised Daito Ridge. In the upraised ridge or island, crystalline schist, such as hornblende schist of intermediate- to high-pressure type, and alpine-type peridotites, whose age is assumed to be pre-Tertiary, have suffered contact metamorphism caused by tholeiitic and alkalic volcanism of Paleocene age.

Detritus from metamorphic and volcanic rocks from the elevated area was distributed, in the surrounding shallow sea, together with Nummulites and other organisms. Steep offshore slopes may have caused frequent slumping and transport of the pebble clasts and organic remains from shallow to deeper waters.

\section{ACKNOWLEDGMENTS}

We are grateful to Assoc. Prof. H. Kagami, Dr. K. Fujioka, and Dr. T. Furuta for critical reading of the manuscript. We are indebted to Prof. N. Nasu for critical suggestions, and also to Miss M. Nash, who helped with English.

\section{REFERENCES}

Arai, S., 1975. Petrology of alpine-type ultramafic complexes in the Sangun zone, western Japan, Ph. D. thesis, Geol. Institute, University of Tokyo.

Finger, L. W., 1972. The uncertainty in the calculated ferric iron content of a microprobe analysis. Ann. Rept. Dir. Geophys. Lab. Yearbook, 71, 600-603.

Ishibashi, K., 1975. Igneous rocks collected from the Daito, Oki-Daito Ridges and from the Okinawa trough. In Kagami, H. (Ed.), Preliminary Report of the Hakuho-Maru Cruise KH-72-2 (The Southwest Japan Arc and Ryukyu Arc Areas), pp. 110-111.

Ishikawa, M., and Aoki, H., 1978. On the volcanic rocks dredged in the Daito Ridge and Oki-Daito Ridge regions, northwestern Philippine Sea with special reference to petrochemical characters on the GDP-15 and GDP-21 Cruises. Earth Sci., 32, 244-253.

Littlejohn, A. L., and Greenwood, H. J., 1974. Lherzolite nodules in basalts from British Coiımbia, Canada. Can. J. Earth Sci., 11, 1288-1308.

Loney, R. A., Himmelberg, G. R., and Coleman, R. G., 1971. Structure and petrology of the alpine-type peridotite at Burro Mountain, California, U.S.A.. J. Petrol., 12, 245309.

Louden, K. E., 1976. Magnetic anomalies in the west Philippine Basin. In Am. Geophys. Union Monogr., 19, pp. 253267.

Miyashiro, A., 1973. Metamorphism and Metamorphic Belts: London (George Allen and Unwin).

Mizuno, A., Okuda, Y., Nagumo, S., Kagami, H., and Nasu, N., 1979. Subsidence of the Daito Ridge and associated basins, north Philippine Sea. Am. Assoc. Petrol. Geol. Mem., 29, 239-243.

Mizuno, A., Shiki, T., and Aoki, H., 1977. Dredged rock and piston and gravity core data from the Daito Ridges and Kyushu-Palau Ridge in the north Philippine Sea. In Geological Studies of the Ryukyu Islands (vol. 2), pp. 107-119.

Mizuno, A., Okuda, Y., Tamaki, K., Kinoshita, Y., Nohara, M., Yuasa, M., Nakajima, N., Murakami, F., Terashima, S., and Ishibashi, K., 1975. Marine geology and geologic history of the Daito Ridges area, northwestern Philippine Sea. Marine Sci., 7, 484-491, 543-548.

Mizuno, A., Yuasa, M., and Tokuyama, H., in press. $\mathrm{K}-\mathrm{Ar}$ dating of hornblende schist from the Daito Ridge, north Philippine Sea. Bull. Geol. Surv. Japan.

Nasu, N., Tomoda, Y., Kobayashi, K., Kagami, H., Uyeda, S., Nagumo, S., Kushiro, I., Ozima, M., Nakazawa, K., Takayanagi, Y., Okada, H., Murauchi, S., Chujo, J., and Ishii, Y., 1977. Multichannel seismic reflection data across the Shikoku Basin and the Daito Ridges, 1976. IPOD-Japan Basic Data Series, 1.

1978. Multichannel seismic reflection data across the Shikoku Basin and the Daito Ridges, 1976. IPOD-Japan Basic Data Series, 2.

O'Hara, M. J., Rechardson, S. W., and Wilson, G., 1971. Garnet peridotite stability and occurrence in crust and mantle. Contr. Mineral. Petrol., 32, 48-68. 
TABLE 4

Summary of Core Samples from Site 445 and Dredge Hauls from the Daito Ridge

\begin{tabular}{|c|c|c|c|c|}
\hline \multicolumn{4}{|c|}{ Core Samples, Site 445 (lithologic unit V) } & \multirow{2}{*}{$\begin{array}{l}\text { Dredge Hauls from the } \\
\text { Daito Ridge }\end{array}$} \\
\hline \multicolumn{2}{|c|}{ Rock Type } & Clasts & Detrital Minerals & \\
\hline \multirow[t]{4}{*}{ Igneous } & Basalt & $\begin{array}{l}\text { Plagioclase- } \\
\text { phyric basalt } \\
\text { Microdolerite } \\
\text { Apyric basalt } \\
\text { Plagioclase- } \\
\text { clinopyroxene- } \\
\text { phyric basalt }\end{array}$ & $\begin{array}{l}\text { Plagioclase } \\
\text { Augite }\end{array}$ & Dolerite \\
\hline & $\begin{array}{l}\text { Alkali } \\
\text { basalt }\end{array}$ & None & $\begin{array}{l}\text { Aegirine-augite } \\
\text { Titaniferous augite }\end{array}$ & \\
\hline & Andesite & None & $?$ & $\begin{array}{l}\text { Two-pyroxene andesite } \\
\text { Hornblende andesite } \\
\text { Augite andesite }\end{array}$ \\
\hline & $\begin{array}{l}\text { Grano- } \\
\text { diorite }\end{array}$ & None & $?$ & Hornblende-biotite granodiorite \\
\hline Ultramafic & & & $\begin{array}{l}\text { Picotite } \\
\text { Enstatite } \\
\text { Magnetite } \\
\text { Serpentine } \\
\text { (pseudomorphs } \\
\text { after olivine) }\end{array}$ & Peridotite (metamorphosed) \\
\hline Metamorphic & & Hornblende schist & $\begin{array}{l}\text { Green hornblende } \\
\text { Epidote } \\
\text { Diopside } \\
\text { Actinolite } \\
\text { (magnetite, } \\
\text { ilmenite) }\end{array}$ & $\begin{array}{l}\text { Hornblende schist } \\
\text { Diopside-chlorite schist } \\
\text { Tremolite schist }\end{array}$ \\
\hline Sedimentary & & $\begin{array}{l}\text { Chert } \\
\text { Nummulites-bearing } \\
\text { limestone } \\
\text { Sandstone }\end{array}$ & $?$ & $\begin{array}{l}\text { Nummulites-bearing limestone } \\
\text { Sandstone } \\
\text { Claystone } \\
\text { Calcareous rock }\end{array}$ \\
\hline Biogenic & & $\begin{array}{l}\text { Nummulites } \\
\text { boninensis } \\
\text { Asterocyclina sp. cf. A } \\
\text { penuria } \\
\text { Operulinoides sp. }\end{array}$ & & $\begin{array}{l}\text { Nummulites boninensis } \\
\text { Asterocyclina } \mathrm{sp} . \\
\text { Discocyclina } \mathrm{sp} \text {. }\end{array}$ \\
\hline
\end{tabular}

Ozima, M., Kaneoka, I., and Ujiie, H., 1977. $\mathrm{Ar}^{40}-\mathrm{Ar}^{39}$ age of rocks, and the development mode of the Philippine Sea. Nature, 267, 816-818.

Shiki, T., Konda, I., Misawa, Y., and Nishimura, A., 1977. Geology and geohistory of the northwestern Philippine Sea, with special reference to the results of the recent Ja- panese research cruises. Mem. Fac. Sci. Kyoto Univ., Ser. Geol. Mineral., 43 (1), 67-78.

Yuasa, M., and Watanabe, T., 1977. Pre-Cenozoic metamorphic rocks from the Daito Ridge in the northern Philippine Sea. J. Japan Ass. Mineral. Petrol. Econ. Geol., 72 (6), 241-251. 